\title{
Interannual variability of primary production and dissolved organic nitrogen storage in the North Pacific Subtropical Gyre
}

\author{
Ya-Wei Luo \\ Woods Hole Oceanographic Institution \\ Hugh W. Ducklow \\ Marjorie A.M. Friedrichs \\ Virginia Institute of Marine Science \\ Matthew Church \\ University of Hawaii \\ David Karl \\ University of Hawaii
}

See next page for additional authors

Follow this and additional works at: https://scholarworks.wm.edu/vimsarticles

Part of the Marine Biology Commons

\section{Recommended Citation}

Luo, Ya-Wei; Ducklow, Hugh W.; Friedrichs, Marjorie A.M.; Church, Matthew; Karl, David; and Doney, Scott C., Interannual variability of primary production and dissolved organic nitrogen storage in the North Pacific Subtropical Gyre (2012). JOURNAL OF GEOPHYSICAL RESEARCH-BIOGEOSCIENCES, 117. 10.1029/2011JG001830

This Article is brought to you for free and open access by the Virginia Institute of Marine Science at W\&M ScholarWorks. It has been accepted for inclusion in VIMS Articles by an authorized administrator of W\&M ScholarWorks. For more information, please contact scholarworks@wm.edu. 


\section{Authors}

Ya-Wei Luo, Hugh W. Ducklow, Marjorie A.M. Friedrichs, Matthew Church, David Karl, and Scott C. Doney 


\title{
Interannual variability of primary production and dissolved organic nitrogen storage in the North Pacific Subtropical Gyre
}

\author{
Ya-Wei Luo, ${ }^{1}$ Hugh W. Ducklow, ${ }^{2}$ Marjorie A. M. Friedrichs, ${ }^{3}$ Matthew J. Church, ${ }^{4}$ \\ David M. Karl, ${ }^{4}$ and Scott C. Doney ${ }^{1}$
}

Received 6 August 2011; revised 20 June 2012; accepted 21 June 2012; published 10 August 2012.

[1] The upper ocean primary production measurements from the Hawaii Ocean Time series (HOT) at Station ALOHA in the North Pacific Subtropical Gyre showed substantial variability over the last two decades. The annual average primary production varied within a limited range over 1991-1998, significantly increased in 1999-2000 and then gradually decreased afterwards. This variability was investigated using a one-dimensional ecosystem model. The long-term HOT observations were used to constrain the model by prescribing physical forcings and lower boundary conditions and optimizing the model parameters against data using data assimilation. The model reproduced the general interannual pattern in the observed primary production, and mesoscale variability in vertical velocity was identified as a major contributing factor to the interannual variability in the simulation. Several strong upwelling events occurred in 1999, which brought up nitrate at rates several times higher than other years and elevated the model primary production. Our model results suggested a hypothesis for the observed interannual variability pattern of primary production at Station ALOHA: Part of the upwelled nitrate input in 1999 was converted to and accumulated as semilabile dissolved organic nitrogen (DON), and subsequent recycling of this semilabile DON supported enhanced primary productivity for the next several years as the semilabile DON perturbation was gradually removed via export.

Citation: Luo, Y.-W., H. W. Ducklow, M. A. M. Friedrichs, M. J. Church, D. M. Karl, and S. C. Doney (2012), Interannual variability of primary production and dissolved organic nitrogen storage in the North Pacific Subtropical Gyre, J. Geophys. Res., 117, G03019, doi:10.1029/2011JG001830.

\section{Introduction}

[2] The North Pacific Subtropical Gyre is one of the Earth's largest biomes [Sverdrup et al., 1942; Karl et al., 2008]. To study this remote and poorly known habitat, the Hawaii Ocean Time series (HOT) Station ALOHA was established in the eastern portion of the North Pacific Subtropical Gyre in 1988 [Karl and Lukas, 1996]. The comprehensive biogeochemical and physical monthly observations at this station provide opportunities to study the temporal variability of the ecosystem in the North Pacific Subtropical Gyre. Primary production is one of the most important indicators of ecosystem dynamics, and by analyzing rates of

\footnotetext{
${ }^{1}$ Department of Marine Chemistry and Geochemistry, Woods Hole Oceanographic Institution, Woods Hole, Massachusetts, USA.

${ }^{2}$ The Ecosystems Center, Marine Biological Laboratory, Woods Hole, Massachusetts, USA.

${ }^{3}$ Virginia Institute of Marine Science, College of William and Mary, Gloucester Point, Virginia, USA.

${ }^{4}$ School of Ocean and Earth Science and Technology, University of Hawaii, Honolulu, Hawaii, USA.

Corresponding author: Y.-W. Luo, Department of Marine Chemistry and Geochemistry, Woods Hole Oceanographic Institution, MS\#25, Woods Hole, MA 02543, USA. (yluo@whoi.edu)

(C)2012. American Geophysical Union. All Rights Reserved. 0148-0227/12/2011JG001830
}

primary production between 1988 and 2007, as measured by the in situ ${ }^{14} \mathrm{C}$-bicarbonate assimilation method $\left({ }^{14} \mathrm{C}-\mathrm{PP}\right)$, Corno et al. [2007], Bidigare et al. [2009] and Saba et al. [2010] concluded that primary production at Station ALOHA was increasing. However, with inclusion of more recent measurements (through 2009), the observations indicate a gradual decline in rates of productivity after 2002 . Further study of this pattern leads to new insights about the mechanisms controlling the variability of primary production in the North Pacific Subtropical Gyre.

[3] The North Pacific Subtropical Gyre is characterized by oligotrophic (low nutrient) conditions, with low concentrations of dissolved inorganic nitrogen $(\mathrm{N})$, a condition maintained by persistent stratification of the upper ocean waters. The maximum winter mixed-layer depth at Station ALOHA averages $\sim 100 \mathrm{~m}$ [Dore et al., 2002], rarely penetrating the top of the nitracline $(110 \pm 10 \mathrm{~m})$ [Dore and Karl, 1996]. The resulting mixed-layer nitrate plus nitrite concentrations average $<10 \mathrm{nM}$ [Karl et al., 2001b], and nitrate plus nitrite to soluble reactive phosphorus ratios within the euphotic zone $(0-150 \mathrm{~m})$ are considerably less $(\sim 2: 1)$ than the Redfield ratio of 16:1 for the average requirement of oceanic phytoplankton [Redfield, 1958].

[4] Although the ratio of total dissolved $\mathrm{N}$ to phosphorus (P) in the euphotic zone is $\sim 19: 1$, higher than the Redfield 


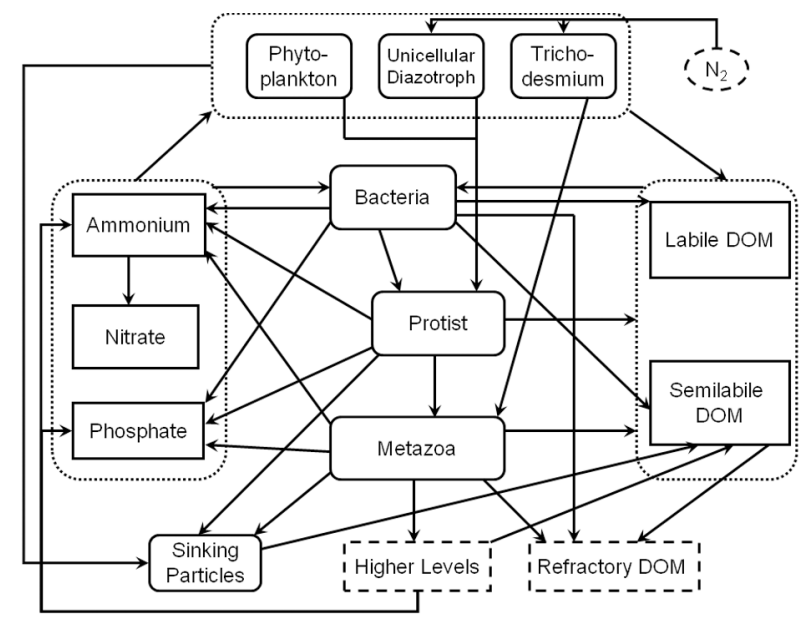

Figure 1. Diagram of the model flows showing trophic structure and state variables. Dashed borders for " $\mathrm{N}_{2}$ " (dinitrogen gas), "Higher Levels" (zooplankton higher than metazoa) and "Refractory DOM" indicate that these elements are not explicitly modeled. Several state variables are grouped by dotted rectangles. A flow arrow ending on a grouping rectangle means the flow applies to all the state variables inside the rectangle.

ratio [Karl et al., 2001a], a large component of the total dissolved $\mathrm{N}$ is refractory dissolved organic $\mathrm{N}$ (DON) [Carlson, 2002]. If we deduct refractory (deep water) DON and refractory dissolved organic P (DOP) from the total dissolved pools, the resulting ratio of bioavailable $\mathrm{N}$ to $\mathrm{P}$ in the euphotic zone is $\sim 14: 1$, slightly lower than the Redfield ratio. In addition, apparently nitrate, nitrite and soluble reactive phosphorus turnover more quickly than DON and DOP and thus appear more bioavailable. The evidence thus indicates the contemporary North Pacific Subtropical Gyre is likely an N-limited habitat. P supply may lead to an enhanced dinitrogen $\left(\mathrm{N}_{2}\right)$ fixation and thus can also indirectly limit the primary productivity [Karl and Letelier, 2008].

[5] As a result of the strong vertical stratification, mesoscale eddy activity can be a major source of nutrients to the mixed layer in the North Pacific Subtropical Gyre [Letelier et al., 2000; Vaillancourt et al., 2003; Calil and Richards, 2010; Calil et al., 2011]. $\mathrm{N}_{2}$ fixation is another important source, which has been estimated to supply up to half of the new N in this region [Karl et al., 1997; Deutsch et al., 2001; Casciotti et al., 2008]. It was found recently that mesoscale eddies can also promote $\mathrm{N}_{2}$ fixation in this region by supplying P- and Silicate-enriched waters [Church et al., 2009]. However, the export of $\mathrm{N}$ may not be tightly coupled with new $\mathrm{N}$ input. The largest oceanic organic matter pool, dissolved organic matter (DOM) [Hedges, 1992], can accumulate in the surface over seasons or even years and be used by phytoplankton and bacteria before it is exported to depth [Carlson et al., 1994; Ducklow et al., 1995; Church et al., 2002; Luo et al., 2010; McCarren et al., 2010]. This recovery of DOM reintroduces $\mathrm{N}$ to the primary producers, a process known as the "microbial loop" [Azam et al., 1983], and thus it has a potential impact on the response of the primary production to new $\mathrm{N}$ input over variable time scales [Jackson and Williams, 1985].
[6] Currently, understanding of marine biogeochemical processes is greatly limited by sampling and analytical constraints. Even the HOT data set at Station ALOHA, which is one of the most extensive and comprehensive in the world's ocean, may lack critical measurements needed to characterize ecosystem functioning. Numeric modeling can be used to fill in gaps of unmeasured and temporally or spatially under-sampled properties. In this study, we utilized a one-dimensional data assimilative ecosystem model developed for the subtropical North Pacific [Luo et al., 2010] to address the observed pattern of interannual to decadal variability of primary production at Station ALOHA in 1991-2009. By conducting a variety of forcing sensitivity experiments with this existing framework, we explored the hypothesis that the increase in ${ }^{14} \mathrm{C}-\mathrm{PP}$ prior to year 2000 and subsequent slow decline reflected a nutrient injection event and retention of the nitrogen as semilabile DOM. Through such experiments it is possible to generate testable hypotheses pertaining to mechanisms for the observed primary production variability that are amenable to direct field experimentation.

\section{Methods}

\subsection{Model Structure and Setup in Standard Experiment}

[7] The model structure and data assimilative framework were adopted from Luo et al. [2010], with temporal coverage in this study spanning 1991-2009. 1989-1990 was utilized as the model spin-up period. The model structure and setup are briefly described here, particularly the $\mathrm{N}$ cycle as it is directly relevant to this study. Refer to Luo et al. [2010] for more details.

[8] The ecosystem model tracked carbon (C), N and P in the state variables with flexible elemental stoichiometry (Figure 1). The model simulated one group of non- $\mathrm{N}_{2}$-fixing phytoplankton, two groups of $\mathrm{N}_{2}$-fixing phytoplankton (unicellular $\mathrm{N}_{2}$ fixers and Trichodesmium), two groups of zooplankton (protists and metazoa), heterotrophic bacteria, sinking particles, DOM which was separated into labile (turnover time of $\sim 1$ day) and semilabile (turnover time of months to years) pools, and three inorganic nutrients (ammonium, nitrate and phosphate). Higher trophic levels and refractory DOM were implicitly represented. The uptake of ammonium and nitrate by phytoplankton was controlled by the Monod equation and its parameters for maximum specific growth rate and half-saturation nutrient concentration [Monod, 1949], with a preference for ammonium over nitrate. $\mathrm{N}_{2}$-fixing phytoplankton also obtained $\mathrm{N}$ through $\mathrm{N}_{2}$ fixation, which was ultimately controlled by light and $\mathrm{P}$ supply. DON was produced by phytoplankton, protist and metazoan excretion and by the dissolution of sinking particles. Labile and semilabile DON were consumed by heterotrophic bacteria at different rates and then were recycled to ammonium. Refractory DON was also produced in these processes and represents an implicit $\mathrm{N}$ loss from the system. The input of nitrate and the export of semilabile DON were also controlled by vertical advection and diffusion. Passively sinking particles' sinking speed generated another export term.

[9] Particulate primary production (P-PP) was diagnosed by subtracting modeled phytoplankton extracellular DOM 
Table 1. Physical Forcings for the Model

\begin{tabular}{ll}
\hline \multicolumn{1}{c}{ Physical Forcing } & Source and Description \\
\hline Photosynthetically active radiation & NCEP reanalysis data \\
Vertical velocity & Estimated from HOT potential density data: temporal variation of $200 \mathrm{~m}$ isopycnal \\
Water temperature & HOT CTD data \\
Mixed layer depth & Depth with $0.5^{\circ} \mathrm{C}$ temperature offset from surface (all state variables fully mixed in mixed layer at each time step) \\
Diffusivity & Not required in mixed layer. Below mixed layer depth (MLD), decreasing exponentially over depth \\
& $k(z)=k_{0} \cdot e^{-\alpha(z-\mathrm{MLD})}, k_{0}=1.1 \times 10^{-4} \mathrm{~m}^{2} \mathrm{~s}^{-1}$ is $k$ at MLD, $\alpha=0.01$. \\
\hline
\end{tabular}

release from modeled net primary production. It has been suggested that the ${ }^{14} \mathrm{C}$-PP measurements may overestimate P-PP because of ${ }^{14} \mathrm{C}$-labeled dissolved organic carbon (DOC) adsorption onto glass fiber filters [Karl et al., 1998]. In this study, however, we used the P-PP as the model equivalent for the available Station $\mathrm{ALOHA}{ }^{14} \mathrm{C}-\mathrm{PP}$ data, both for the model optimization with data assimilation (see below) and for the analysis of model performance. The underlying assumption was that the overestimation percentage of ${ }^{14} \mathrm{C}-\mathrm{PP}$ measurements was constant, so that it would not affect our variability analysis.

[10] HOT ${ }^{14} \mathrm{C}$-PP rates were measured mostly in upper $175 \mathrm{~m}$ before 2001, while only in upper $125 \mathrm{~m}$ afterwards. For consistency, all the ${ }^{14} \mathrm{C}$-PP profile were linearly interpolated and integrated in upper $137.5 \mathrm{~m}$ using the measurements at $5 \mathrm{~m}, 25 \mathrm{~m}, 45 \mathrm{~m}, 75 \mathrm{~m}, 100 \mathrm{~m}$ and $125 \mathrm{~m}$. Note that the ${ }^{14} \mathrm{C}$-PP below this depth ranged $\sim 2-4 \%$ of the total rate, shown by the measurements before 2001 .

[11] The model covered the surface $200 \mathrm{~m}$ at Station ALOHA $\left(22^{\circ} 45^{\prime} \mathrm{N}, 158^{\circ} \mathrm{W}\right)$ with 25 vertical layers. Only the results from surface $150 \mathrm{~m}$ were analyzed to represent the euphotic zone. The time step was $1 \mathrm{~h}$. The model was forced by physical forcings (Table 1) and bottom boundary conditions, which were derived and linearly interpolated from HOT data (http://hahana.soest.hawaii.edu/hot/hot_jgofs.html). An exception was the photosynthetically active radiation (PAR) that was derived from NCEP reanalysis data (http://www. esrl.noaa.gov/psd/data/reanalysis/). Vertical velocity was derived from HOT potential density data. An isopycnal with average depth of $200 \mathrm{~m}$ was selected, and the first order derivative with time of this isopycnal's depth was used as the estimated vertical velocity at $200 \mathrm{~m}$. Then the vertical velocity was linearly interpolated to the surface by assuming zero vertical velocity at the surface. Physical fluxes of nitrate, phosphate and semilabile DOM (including its $\mathrm{C}, \mathrm{N}$ and $\mathrm{P}$ components) were specified at the model bottom boundary using concentrations estimated from the HOT data. Sinking particles (including their $\mathrm{C}, \mathrm{N}$ and $\mathrm{P}$ components) exported across the model bottom boundary. Bottom boundary fluxes of other state variables were set to zero because of their low concentrations/biomass and low gradients at the depth of the model bottom boundary.

[12] As in Luo et al. [2010], an existing one-dimensional data assimilative framework [Friedrichs et al., 2007] was utilized. Specifically, the variational adjoint technique [Lawson et al., 1995] was used to objectively optimize model parameters by minimizing the differences between the simulated values and HOT observations. Seventeen types of observations were assimilated (Table 2).

[13] For the purposes of both the model bottom boundary conditions and the data assimilation, the $\mathrm{C}, \mathrm{N}$ and $\mathrm{P}$ components of semilabile DOM were derived by assuming refractory DOM was uniformly distributed at the Station ALOHA, and DOM in the deep ocean was all refractory [Carlson, 2002]. Thus for each measured DOM profile at Station ALOHA, the semilabile DOM concentration was derived by subtracting the measured DOM concentration at $1,000 \mathrm{~m}$ from the profile.

\subsection{Forcing Sensitivity Experiments}

[14] To further investigate the mechanisms for the modeled P-PP variability in the standard experiment, several forcing sensitivity experiments were conducted (see below).

Table 2. Comparison Between the Assimilated Observations and Their Model Equivalents (Mean \pm Standard Deviation of All Points Without Differentiation of Depth or Time) ${ }^{\mathrm{a}}$

\begin{tabular}{|c|c|c|c|c|c|c|c|c|c|}
\hline & PHYn & CHL & P-PP & $\mathrm{BAc}$ & $\mathrm{BP}$ & NO3 & $\mathrm{PO} 4$ & $\mathrm{MZc}$ & \\
\hline \multirow[t]{2}{*}{ Assimilated observations } & 0.11 & 0.13 & 0.34 & 0.31 & 0.039 & 0.0031 & 0.059 & 0.17 & \\
\hline & \pm 0.07 & \pm 0.07 & \pm 0.23 & \pm 0.12 & \pm 0.033 & \pm 0.0021 & \pm 0.032 & \pm 0.06 & \\
\hline \multirow[t]{3}{*}{ Model equivalents } & 0.08 & 0.13 & 0.34 & 0.26 & 0.033 & 0.0015 & 0.010 & 0.15 & \\
\hline & \pm 0.04 & \pm 0.04 & \pm 0.17 & \pm 0.13 & \pm 0.024 & \pm 0.0072 & \pm 0.003 & \pm 0.02 & \\
\hline & $\mathrm{sDOC}$ & $\mathrm{sDON}$ & sDOP & POC & PON & POP & STc & STn & STp \\
\hline \multirow[t]{2}{*}{ Assimilated observations } & 33 & 3.3 & 0.18 & 1.6 & 0.25 & 0.010 & 2.3 & 0.29 & 0.0095 \\
\hline & \pm 10 & \pm 0.7 & \pm 0.05 & \pm 0.7 & \pm 0.10 & \pm 0.005 & \pm 0.8 & \pm 0.10 & \pm 0.0038 \\
\hline \multirow[t]{2}{*}{ Model equivalents } & 39 & 3.4 & 0.18 & 1.3 & 0.19 & 0.012 & 2.3 & 0.30 & 0.0087 \\
\hline & \pm 7 & \pm 0.4 & \pm 0.03 & \pm 0.6 & \pm 0.08 & \pm 0.005 & \pm 0.4 & \pm 0.05 & \pm 0.0019 \\
\hline
\end{tabular}

${ }^{\mathrm{a}}$ All the data points are profiles over 0-200 m except NO3, PO4, MZc, STc, STn and STp. All concentrations are in mmol ${ }^{-3}$ except for CHL, which is in $\mathrm{mg} \mathrm{m}^{-3}$; P-PP and BP are in mmol C m $\mathrm{m}^{-3} \mathrm{~d}^{-1}$; and STc, STn and STp are in mmol m $\mathrm{m}^{-2} \mathrm{~d}^{-1}$. PHYn: phytoplankton nitrogen biomass; CHL, phytoplankton chlorophyll $a$; P-PP: ${ }^{14} \mathrm{C}$-primary production for observation and particulate primary production for model; BAc and BP: heterotrophic bacteria carbon biomass and production; NO3: nitrate (nitrate + nitrite in observation) at $10 \mathrm{~m}$; PO4: phosphate at $10 \mathrm{~m}$; MZc: average mesozooplankton carbon biomass in surface 0-175 m; sDOC, sDON and sDOP: semilabile dissolved organic carbon, nitrogen and phosphorus; POC, PON and POP: particulate organic carbon, nitrogen and phosphorus, note observations for carbon and phosphorus did not separate organic matter but measured gross particulate carbon and phosphorus; STc, STn and STp: sediment trap (particulate export) carbon, nitrogen and phosphorus data at $150 \mathrm{~m}$. 

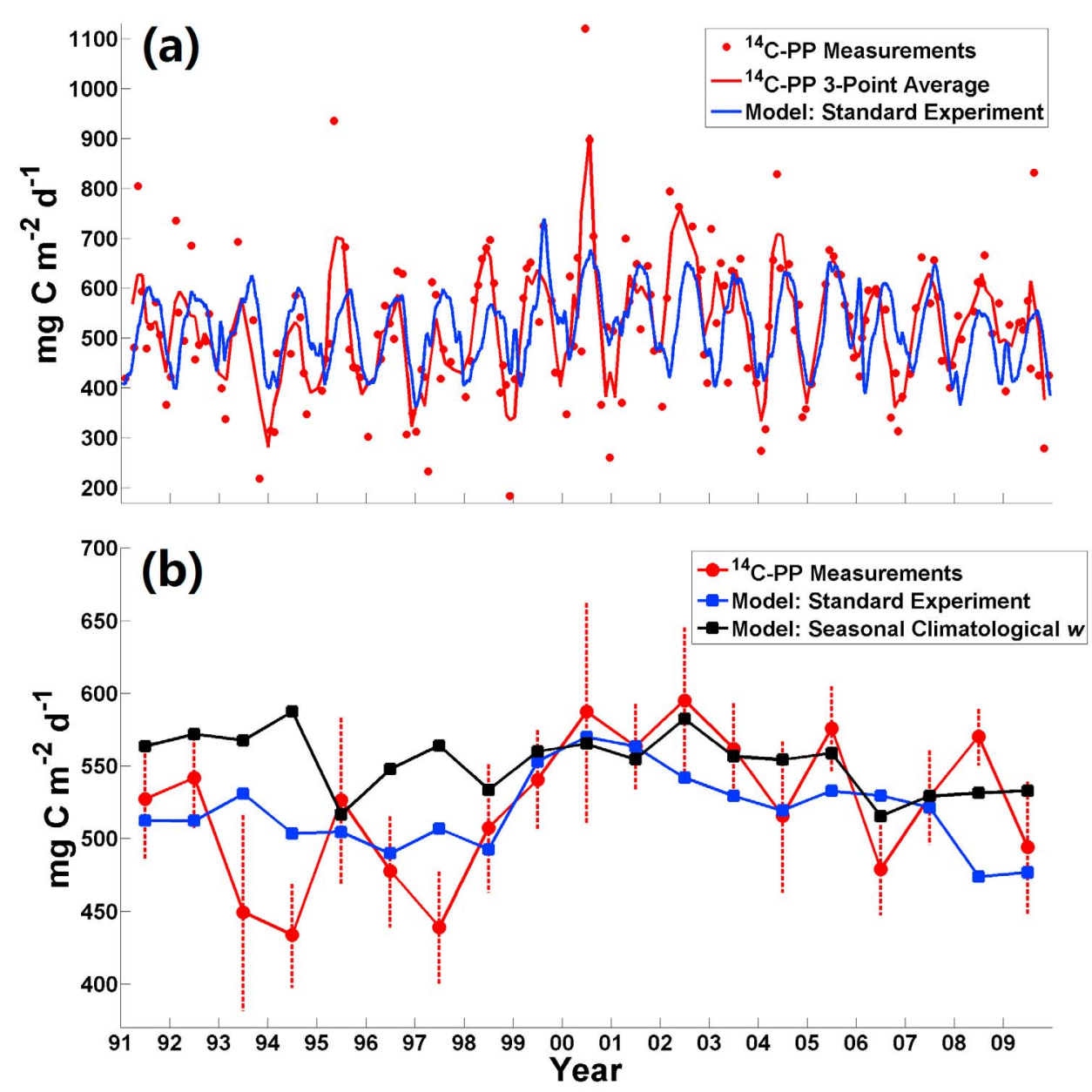

Figure 2. (a) Comparison of depth-integrated ${ }^{14} \mathrm{C}$ primary production $\left({ }^{14} \mathrm{C}-\mathrm{PP}\right)$ measurements (red dots) and their 3-point running average (red line) with the model particulate primary production (P-PP) in the standard experiment (monthly running average, blue line) at Station ALOHA in 1991-2009. (b) The annual means: ${ }^{14} \mathrm{C}-\mathrm{PP}$ measurements with standard errors (red), model P-PP in the standard experiment (blue) and model P-PP in the experiment using seasonal climatological vertical velocity $w$ (black).

\subsubsection{Experiments to Identify Impacts of Forcing Variability}

[15] A series of sensitivity experiments was set up to investigate how the physical forcing terms contribute to the modeled P-PP variability. Although the data assimilation scheme used in this study can force the model to match the average measurements and the amplitudes of seasonal variability by optimizing model parameters, interannual variability in our configuration cannot be generated by changes in model parameters because the parameter values were held constant through all the years. The interannually varying forcings must explain modeled variability. A series of sensitivity experiments was conducted using combinations of time-varying forcing and seasonal climatological forcing of the different variables: the time-varying forcings incorporated both interannual and seasonal variations (those used in the standard experiment), while the seasonal climatological forcings repeated the seasonal climatological averages over all model years and thus did not include interannual variability. Exceptions were the seasonal climatological forcings of vertical velocity and bottom boundary conditions of nitrate and phosphate. Instead of seasonal climatologies, we used values from a typical year (2003) repeated in each model year because these forcings did not have well characterized seasonal patterns and using climatological averages would smooth out essential subannual variability. These forcings are still referred as "seasonal climatological forcing" to simplify the terminology of this paper.

[16] In a first set of experiments, seasonal climatological forcing was used only for a single forcing term while timevarying forcing was used for all other forcing terms. That is, in each experiment only one forcing term in the standard experiment was adjusted to the seasonal climatology. Thus if the interannual variability pattern of the modeled P-PP changed substantially from the standard experiment then it was likely that the adjusted forcing term can be justified as a contributing factor.

[17] In a second set of complementary experiments, timevarying forcing was used for only one forcing factor while all of the other forcings were seasonal climatologies. Thus if the experiment reproduced the modeled P-PP interannual variability pattern to some extent, then it was likely that the sole time-varying forcing term used in the experiment can be justified as a contributing factor. 
Table 3. Interannual Variability Pattern of Annual Average Primary Production Rates in Forcing Experiments ${ }^{\mathrm{a}}$

\begin{tabular}{|c|c|c|c|c|c|}
\hline & $\begin{array}{c}\text { 1991-1998 } \\
\text { Average }\end{array}$ & 2000 & $\begin{array}{l}2000 \text { Minus } \\
1991-1998\end{array}$ & $\begin{array}{l}\text { Slope in } \\
2000-2009\end{array}$ & $p$ \\
\hline${ }^{14} \mathrm{C}$ Measurements & 488 & 587 & 99 & $-7.9 \pm 3.8$ & 0.068 \\
\hline $\begin{array}{l}\text { Standard experiment: All } \\
\text { time-varying forcings }\end{array}$ & 507 & 570 & 63 & $-9.4 \pm 1.5$ & $\mathbf{0 . 0 0 0}$ \\
\hline $\begin{array}{l}\text { Experiments: All seasonal } \\
\text { climatological forcings }\end{array}$ & 552 & 551 & -1 & 0.0 & 0.621 \\
\hline \multicolumn{6}{|c|}{ Experiments: Time-Varying Forcings Except for Identified Forcing Variables ${ }^{\mathrm{b}}$} \\
\hline Vertical velocity & $557(+50)$ & $565(-5)$ & 9 & $-5.1 \pm 1.5$ & 0.011 \\
\hline PAR & $515(+8)$ & $573(+3)$ & 58 & $-8.9 \pm 2.0$ & 0.002 \\
\hline Water temperature & $509(+2)$ & $571(+1)$ & 62 & $-9.0 \pm 1.9$ & 0.001 \\
\hline $\begin{array}{l}\text { Mixed-layer depth and } \\
\text { eddy diffusivity }\end{array}$ & $519(+12)$ & $580(+10)$ & 61 & $-11.5 \pm 1.6$ & 0.000 \\
\hline Nitrate BBC & $528(+21)$ & $649(+79)$ & 121 & $-16.1 \pm 2.4$ & 0.000 \\
\hline Phosphate BBC & $508(+1)$ & $570(0)$ & 62 & $-7.8 \pm 1.5$ & 0.001 \\
\hline Semilabile DOC BBC & $506(-1)$ & $561(-9)$ & 55 & $-8.9 \pm 1.5$ & 0.000 \\
\hline Semilabile DON BBC & $499(-8)$ & $523(-47)$ & 24 & -2.9 & 0.194 \\
\hline Semilabile DOP BBC & $502(-5)$ & $570(0)$ & 68 & $-9.4 \pm 1.6$ & 0.000 \\
\hline \multicolumn{6}{|c|}{ Experiments: Seasonal Climatological Forcings Except for Identified Forcing Variables ${ }^{\mathrm{c}}$} \\
\hline Vertical velocity ${ }^{\mathrm{d}}$ & $555(+48)$ & $657(+87)($ in 1999) & $\begin{array}{c}101 \\
\text { (1999 Minus } \\
\text { 1991-1998) }\end{array}$ & $\begin{array}{l}-7.5 \pm 5.7 \\
\text { (Slope in } \\
1999-2009 \text { ) }\end{array}$ & 0.039 \\
\hline PAR & $542(+35)$ & $548(-22)$ & 6 & -0.9 & 0.319 \\
\hline Water temperature & $548(+41)$ & $550(-20)$ & 2 & -0.4 & 0.774 \\
\hline $\begin{array}{l}\text { Mixed-layer depth and } \\
\text { eddy diffusivity }\end{array}$ & $549(+42)$ & $560(-10)$ & 11 & $-1.7 \pm 0.6$ & 0.019 \\
\hline Nitrate BBC & $564(+57)$ & $534(-36)$ & -30 & $2.1 \pm 1.0$ & 0.076 \\
\hline Phosphate BBC & $553(+46)$ & $552(-18)$ & -1 & 0.0 & 0.490 \\
\hline Semilabile DOC BBC & $552(+45)$ & $554(-16)$ & 2 & -0.5 & 0.154 \\
\hline Semilabile DON BBC & $557(+50)$ & $569(-1)$ & 12 & $-4.2 \pm 0.5$ & 0.000 \\
\hline Semilabile DOP BBC & $552(+45)$ & $552(-18)$ & 0 & $-0.5 \pm 0.1$ & 0.001 \\
\hline
\end{tabular}

\subsubsection{Pulse Experiment}

[18] To better isolate the model response, we also conducted an idealized "pulse" experiment in which the timevarying forcings were used only for 1999 while the seasonal climatological forcings were used for all other years.

[19] The optimized (by data assimilation) model parameters in the standard experiment were used for all of the forcing sensitivity experiments; that is, the data assimilation scheme was not used to re-optimize parameters to the observations for any of the sensitivity experiments.

\section{Results and Discussion}

\subsection{Interannual Variability of Measured Primary Production}

[20] There were 181 vertically resolved ${ }^{14} \mathrm{C}$-PP determinations at Station ALOHA measured between 1991 and 2009 (Figure 2a) with at least 8 profiles for each year, at approximately monthly intervals, except for 1993, which had only 6 available profiles. The arithmetic means of the ${ }^{14} \mathrm{C}-\mathrm{PP}$ determinations were calculated for each year (Figure $2 b$ ). Figure $2 b$ shows that the temporal evolution of the annual average primary production at Station ALOHA can be roughly grouped into several stages over the study period: (1) ${ }^{14} \mathrm{C}-\mathrm{PP}$ varied in $1991-1998$ with an average of
$488 \pm 15$ (standard error, same hereafter) $\mathrm{mg} \mathrm{C} \mathrm{m}^{-2} \mathrm{~d}^{-1}$; (2) ${ }^{14} \mathrm{C}$-PP exceeded the previous variation range in 1999 , 2000 and maintained high rates in 2000-2002 (582 \pm 10 $\mathrm{mg} \mathrm{C} \mathrm{m} \mathrm{m}^{-2} \mathrm{~d}^{-1}$ ), which was significantly greater (Student's $t$-test $p<0.01)$ than measured during the previous stage; and (3) ${ }^{14} \mathrm{C}$-PP then gradually decreased through 2009. Linear regression analyses for the average annual ${ }^{14} \mathrm{C}-\mathrm{PP}$ between 2000 (the first year when the ${ }^{14} \mathrm{C}$-PP reached the peak) and 2009 revealed a decreasing trend of $7.9 \pm 3.8 \mathrm{mg}$ $\mathrm{C} \mathrm{m}^{-2} \mathrm{~d}^{-1} \mathrm{yr}^{-1}\left(p=0.07 ; \mathrm{R}^{2}=0.36\right)$ (Table 3$)$. The annual average ${ }^{14} \mathrm{C}$-PP of $494 \mathrm{mg} \mathrm{C} \mathrm{m}^{-2} \mathrm{~d}^{-1}$ in 2009 suggested that the primary production may have returned to the observed range for 1991-1998. We utilized the ecosystem model to explore the hypothesis that the observed increase in ${ }^{14} \mathrm{C}$-PP between 1999 and 2002, and subsequent decline post 2002, was supported by a nutrient injection event and subsequent retention of the $\mathrm{N}$ in the upper ocean as semilabile DOM.

\subsection{Modeled Particulate Primary Production in the Standard Experiment}

[21] The model parameters were first optimized by data assimilation, which greatly minimized the model misfits to the observations [Luo et al., 2010]. The average values of the model variables were mostly comparable to the observations 
(Table 2). The only exceptions were surface (at depth of 10 $\mathrm{m})$ concentration of phosphate, which were underestimated by the model. However, the model surface primary productivity was still N-limited even with the underestimated surface phosphate, so that the performance of the modeled $\mathrm{N}$ cycle was not impacted. After data assimilation the model successfully reproduced the observed seasonality in productivity (Figure 2a).

[22] The modeled annual averages of P-PP in the standard experiment were low in 1991-1998, then increased in 19992000 and decreased after 2000 (Figure 2b), which was similar to the pattern of the ${ }^{14} \mathrm{C}$-PP measurements, except that the modeled P-PP started to decrease two years earlier (after 2000) than the ${ }^{14} \mathrm{C}-\mathrm{PP}$ measurements (after 2002) (Figure 2b). To facilitate the evaluation of the model performance in reproducing this interannual primary production pattern, we looked at three indicators: the average annual mean value for 1991-1998 to represent the first stage; whether the annual value in 2000 was higher than the average value in 1991-1998 to represent the stage shift; and the linear trend between 2000 and 2009 (Table 3). The average modeled P-PP in the standard experiment in 1991-1998 was $507 \pm 4.5 \mathrm{mg} \mathrm{C} \mathrm{m}^{-2} \mathrm{~d}^{-1}, \sim 20 \mathrm{mg} \mathrm{C} \mathrm{m}^{-2} \mathrm{~d}^{-1}$ greater than the measured rates, because the model was not able to reproduce the low measurements in 1993, 1994 and 1997. The modeled P-PP also had a smaller increase of $63 \mathrm{mg} \mathrm{C}$ $\mathrm{m}^{-2} \mathrm{~d}^{-1}$ in 2000 , over the 1991-1998 baseline, compared to the measurements. The modeled annual value in 2000 was still significantly higher than the mean of the modeled values in 1991-1998 (Student's $t$-test, $p<0.001$ ). The decreasing rate of modeled P-PP in 2000-2009 was $\sim 9.4 \pm 1.5 \mathrm{mg} \mathrm{C}$ $\mathrm{m}^{-2} \mathrm{~d}^{-1} \mathrm{yr}^{-1}$, similar to that based on the measured rates.

\subsection{Contributing Forcings for the Modeled Interannual Variability of Primary Production}

[23] Before conducting the sensitivity experiments, the model was first tested using the seasonal climatological forcings over all years. The simulation approached a cyclostationary seasonal variation with a steady state annual average P-PP (see Figure S1 in Text S1 in the auxiliary materials), ${ }^{1}$ indicating that the seasonal climatological forcings did not introduce the interannual variability of the simulated P-PP.

[24] The experiments replacing a single forcing term in turn in the standard experiment with seasonal climatological forcing showed that three forcing terms substantially affected the modeled P-PP pattern: vertical velocity and the nitrate and semilabile DON bottom boundary conditions (Table 3). When the seasonal climatology was used for the vertical velocity, the modeled shift toward elevated modeled P-PP in 1999-2000 disappeared and the downward trend after 2000 was lower (Figure $2 b$ and Table 3 ). When the seasonal climatology was used for the nitrate bottom boundary condition, the increase of the modeled P-PP in 2000 was even higher, and the decrease of P-PP after 2000 was faster (Table 3 ). In other words, the standard timevarying, nitrate bottom boundary condition actually weakened the pattern of the modeled P-PP variability. When the seasonal climatology was used for the semilabile DON

\footnotetext{
${ }^{1}$ Auxiliary materials are available in the HTML. doi:10.1029/ 2011JG001830.
}

bottom boundary condition, the increase of P-PP in 2000 became smaller (Table 3 ). This was because the semilabile DON bottom boundary condition seasonal climatology exhibited lower concentrations in 1999 and 2000 than in the standard time-varying values (derived from the observations). Thus the accumulated semilabile DON was exported by physical diffusion more quickly in the seasonal climatological experiment in 1999 and 2000, and less N was recycled to support primary production (the details of this effect are discussed in the next section).

[25] The identified contributing factors were also confirmed by the other set of sensitivity experiments with one time-varying forcing term. In the sensitivity experiment where time-varying forcing was applied only for the vertical velocity (with seasonal climatologies for the other forcings), the P-PP peak occurred earlier in time and was larger in magnitude than in the standard results (Table 3). In the standard experiment, the effect of the time-varying vertical velocity is damped partially by an opposing effect from the time-variations in the nitrate bottom boundary condition. As expected, with only a time-varying nitrate bottom boundary condition, the model produced an opposite pattern from the standard results with a decrease of P-PP in 2000 and increasing P-PP after 2000 (Table 3). The time-varying semilabile DON bottom boundary conditions alone produced a much smaller P-PP increase in 2000, and a significant decrease after 2000 (Table 3). The pair of sensitivity experiments testing the effect of semilabile DON bottom boundary conditions suggested that the decreasing P-PP trend in the standard experiment was partly contributed by the bottom boundary condition of semilabile DON. Unfortunately there were no DON measurements after 2000 at Station ALOHA, and the time-varying semilabile DON bottom boundary condition after 2000 was constructed indirectly from DOC measurements using a constant $\mathrm{C}: \mathrm{N}$ ratio of 11:1. Thus we cannot conclusively affirm the effect of the semilabile DON bottom boundary condition after 2000.

[26] Together, these sensitivity experiments indicated that the interannual variability of the vertical velocity, modulated and partially opposed by the nitrate bottom boundary condition, was the principal forcing term contributing to the modeled interannual variability in P-PP. As discussed above, the vertical velocity (Figure 3) was derived from the monthly measurements of potential density at Station ALOHA and therefore may have incorporated some information on mesoscale phenomena (e.g., eddies, Rossby waves, etc.), which could be a physical mechanism for the interannual variability of primary production in the North Pacific Subtropical Gyre.

\subsection{Responses of the Modeled Primary Production}

[27] Although the forcing terms were the ultimate causes for the interannual variability of modeled primary production, further analysis was necessary to study how the modeled primary production variability responded to these forcings. In this N-limited system, the modeled annual average P-PP closely followed the modeled total $\mathrm{N}$ inventory $(\mathrm{N}$ from all state variables) over the $0-150 \mathrm{~m}$ depth range (correlation $r=0.83, p<0.001, n=19$ ) (Figure 4). Thus the variability in model primary production greatly depended on the time rate of change in the bioavailable $\mathrm{N}$ inventory. 


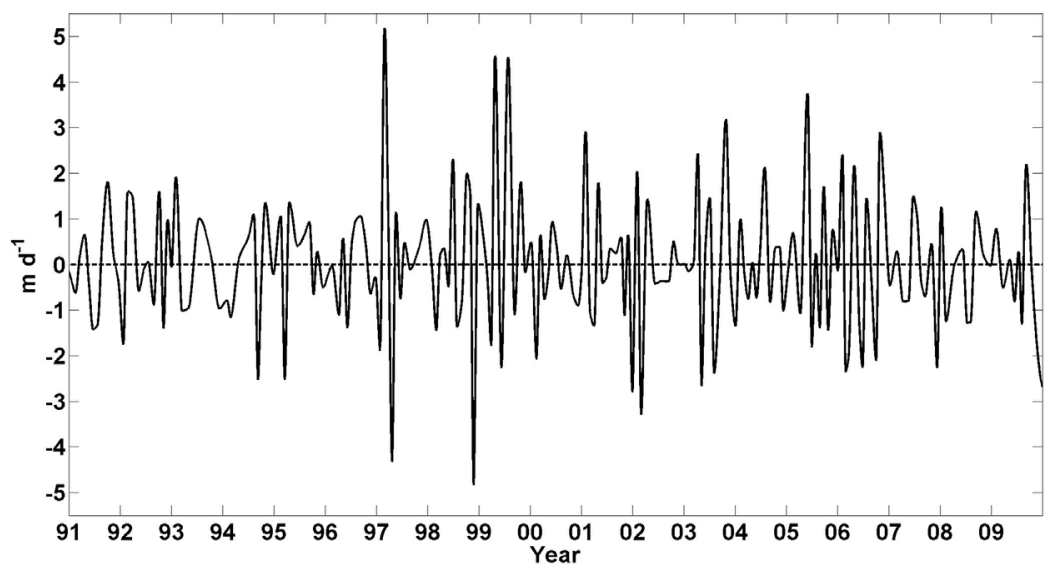

Figure 3. Standard time-varying vertical velocity forcing of the model at $200 \mathrm{~m}$. Positive velocity indicates upward.

[28] The variability in model $\mathrm{N}$ inventory $(0-150 \mathrm{~m})$, and thus simulated P-PP, is most strongly influenced by variability in $\mathrm{N}_{2}$ fixation and the physical transport of nitrate and semilabile DON across $150 \mathrm{~m}$ depth (Figure 5a). The modeled time series of these three terms (Figure $5 \mathrm{~b}$ ) shows that the nitrate flux exhibited the largest variability and that the amplitude and phasing of the variability were positively correlated $(r=0.94, p<0.001, n=6,940)$ with vertical velocity (Figure 3 ). The variability of the semilabile DON net balance was weaker than that of nitrate. Semilabile DON and nitrate net balances were somewhat negatively correlated (Figure $5 \mathrm{~b}$ ) with semilabile DON balance lagging 5 days behind that of nitrate (lagged correlation $r=-0.29$, $p<0.001, n=6,935)$. Semilabile DON export followed the upwelling of nitrate (Figure 5b) indicating the system exported some of the nitrate input as semilabile DON. Modeled rates of $\mathrm{N}_{2}$ fixation did not respond to variations in vertical velocity, but demonstrated relatively stable seasonal variations, suggesting these rates were mostly controlled by biological processes or seasonally variable physical forcings such as PAR and water temperature.

[29] Time series of the time rate of change of the $\mathrm{N}$ inventory for these three terms revealed that the most notable event was a high nitrate input in 1999 (Figure 5c) associated with 3 strong upwelling events occurring in the same year (Figure 3 and Figure $5 \mathrm{~b}$ ). These results suggest the high nitrate input in 1999 changed the $\mathrm{N}$ balance of the system and increased the model total $\mathrm{N}$ inventory and P-PP for a several year period after the upwelling event. In the next section we use an idealized pulse experiment to characterize the model relaxation time-scale following an upwelling event.

\subsection{Pulse Experiment and Semilabile DON Storage}

[30] The pulse experiment used seasonal climatological forcing for all years except for 1999 when time-varying forcing was applied to generate a pulse of high nitrate supply. The results showed that the model was in a balanced state on annual basis before 1999. After the high nitrate input, a peak of elevated P-PP occurred in 2000, and it took about 5 years for the modeled P-PP to return to the previous level (Figure 6). The modeled P-PP still closely followed the total $\mathrm{N}$ inventory (Figure 6) as in the standard model experiment. The $\mathrm{N}$ input in 1999 was stored in the system and gradually exported in the following years, generating the modeled interannual P-PP variability pattern.

[31] We further analyzed the $\mathrm{N}$ budget within the model pulse experiment. To simplify the presentation, $\mathrm{N}$ fluxes and

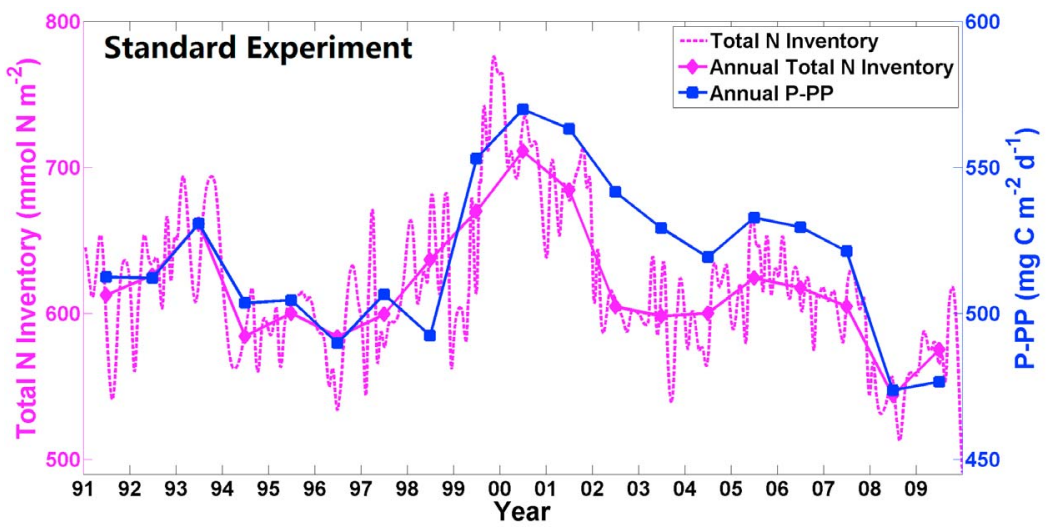

Figure 4. Comparison of the annual mean particulate primary production (P-PP) (blue) and the total N inventory over $0-150 \mathrm{~m}$ (both annual average and full time series) (magenta) in the standard model experiment. 

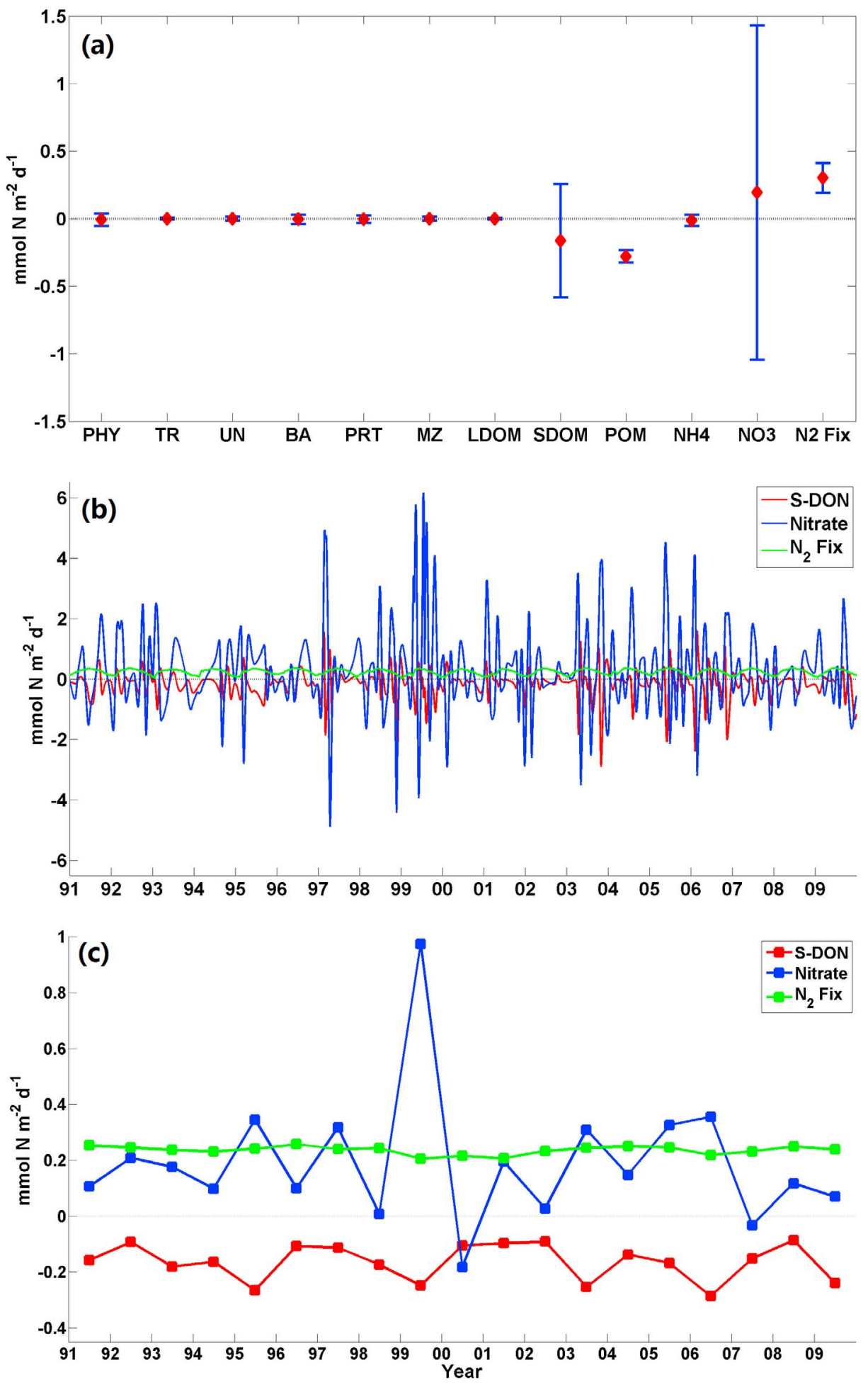

Figure 5. Analysis of $\mathrm{N}$ net balances of the model over 0-150 $\mathrm{m}$ in 1991-2009. (a) Mean and standard deviation of the net balance time series of $\mathrm{N}$ component of each state variable and of the $\mathrm{N}_{2}$ fixation rate (N2 Fix). PHY: non- $\mathrm{N}_{2}$-fixing phytoplankton, TR and $\mathrm{UN}$ : $\mathrm{N}_{2}$-fixing Trichodesmium and unicellular $\mathrm{N}_{2}$ fixers, BA: heterotrophic bacteria, PRT and MZ: protist and metazoa, LDOM and SDOM: labile and semilabile DOM, POM: sinking particles, NH4: ammonium, NO3: nitrate. (b) time series and (c) annual means of $\mathrm{N}$ net balances in the forms of semilabile DON (S-DON, red), nitrate (blue) and $\mathrm{N}_{2}$ fixation (green). 


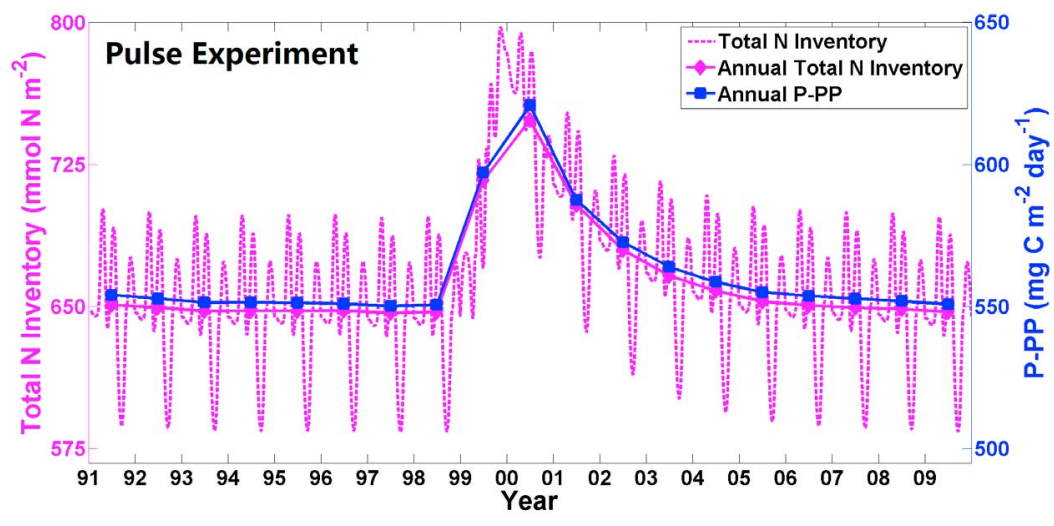

Figure 6. Results of the pulse experiment showing modeled annual mean particulate primary production (P-PP) (blue) and modeled time series and annual means of total $\mathrm{N}$ inventory (magenta) in 0-150 $\mathrm{m}$.

inventories were normalized to the annual rate of $\mathrm{N}$ uptake by primary producers, which was assigned a value of 100 units. In the balanced state in 1991-1998, new $\mathrm{N}$ input,

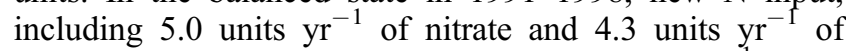
nitrogen fixation, was balanced by 9.3 units $\mathrm{yr}^{-1}$ of $\mathrm{N}$

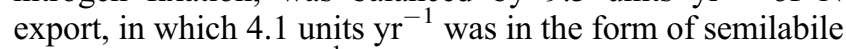
DON and 5.2 units $\mathrm{yr}^{-1}$ was in sinking particles (Figure 7a). The resulting f-ratio was $\sim 0.09$. Semilabile DON was pro-

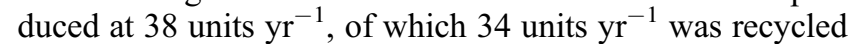
by heterotrophic bacteria to support primary production (Figure $7 \mathrm{a}$ ). Thus one third of the $\mathrm{N}$ requirement for the primary producers was processed through the heterotrophic bacteria-semilabile DON pathway.

[32] In the 1999 perturbation in the pulse experiment, the

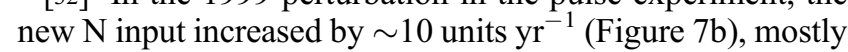
from nitrate input (data not shown), which effectively doubled the new $\mathrm{N}$ input compared to the balanced state (Figure 7a). Export responded by increasing $\sim 2$ units $\mathrm{yr}^{-1}$ in both semilabile DON and other forms, which resulted in a

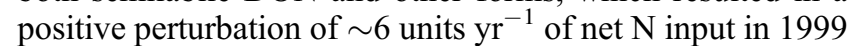
(Figure 7b). The net $\mathrm{N}$ flux was negative in the following years (Figure $7 \mathrm{~b}$ ), as the result of increased export and decreased nitrate input (because upper ocean nitrate concentration was slightly higher after 1999). It required almost 5 years of negative net $\mathrm{N}$ input to balance these 6 units $\mathrm{yr}^{-1}$ of net $\mathrm{N}$ input in 1999 (Figure 7b).

[33] The accumulated $\mathrm{N}$ was stored mainly in the semilabile DON pool (Figure 7c). The production of semilabile DON, i.e., the input, increased by 4 and 6 units $\mathrm{yr}^{-1}$ in 1999 and 2000, respectively (Figure 7c). Note the increase of nitrate flux occurred in the second half of 1999, and 2000 started with an already elevated $\mathrm{N}$ inventory (Figure 6). Thus the annual average anomaly of semilabile DON production in 2000 was even higher than 1999. The consumption of semilabile DON decreased slightly in 1999 (Figure 7c) because the high nitrate input and the consequent production of ammonium and labile DON inhibited heterotrophic bacteria from using semilabile DON in the model. As the net result of increased production and decreased consumption of semilabile DON, the semilabile DON inventory increased and reached its highest value in 2000. Thus in 2000 and the following years, when there was no increased input of nitrate, the elevated semilabile DON concentration led to enhanced semilabile DON consumption by heterotrophic bacteria (Figure 7c). The ratio of the increased semilabile DON consumption by heterotrophic bacteria to the increased $\mathrm{N}$ uptake by primary producers in 2000-2004 was $\sim 0.4$ (Figure 7c), which is consistent with the balanced state where one third of $\mathrm{N}$ assimilation by primary production was from semilabile DON (Figure 7a).

[34] In summary, the pulse experiment showed how a portion of the excess $\mathrm{N}$ from nitrate input in 1999 accumulated in the model domain in the relatively stable semilabile DON pool (Figure 7c) and was exported slowly over the next several years, driven by approximately equal contributions from sinking particle flux and physical transport of semilabile DON (Figure 7b). The $\mathrm{N}$ storage into the semilabile DON pool occurred relatively quickly after the excess nitrate input (Figure 6). The balanced state showed that the time scale for semilabile DON relative to removal via export was $\sim 5$ years (inventory of 21 units divided by 4.1 units $\mathrm{yr}^{-1}$ of export) (Figure 7a). This time scale was justified by the model setup: the modeled semilabile DON profiles, and thus also vertical gradients, were constrained by the measurements through the data assimilation; the physical transport was also constrained by direct and indirect measurements. Thus a positive anomaly to the semilabile DON pool, once mixed with the existing semilabile DON, also takes $\sim 5$ years to relax back to the original steady state value (or slightly shorter as the vertical gradient in semilabile DON between the euphotic zone and the model bottom boundary condition also increases, enhancing vertical transport). These factors contributed to the return of the pulse experiment to steady state $\sim 5$ years following the excess nitrate input in 1999.

[35] In this way, the accumulation of $\mathrm{N}$ in the semilabile DON pool can slow the transfer of $\mathrm{N}$ to the sinking particles. If there were no semilabile DON pool to store the accumulated $\mathrm{N}$, the model would return to the balanced state much more quickly.

\subsection{Hypothesis and Limitations}

[36] This modeling study suggested a hypothesis to explain the observed interannual variability in primary production over the past two decades at Station ALOHA. Primary productivity at this station had been relatively steady between 1991 and 1998 until several mesoscale upwelling events transported excess nitrate into the euphotic zone in 
(a)
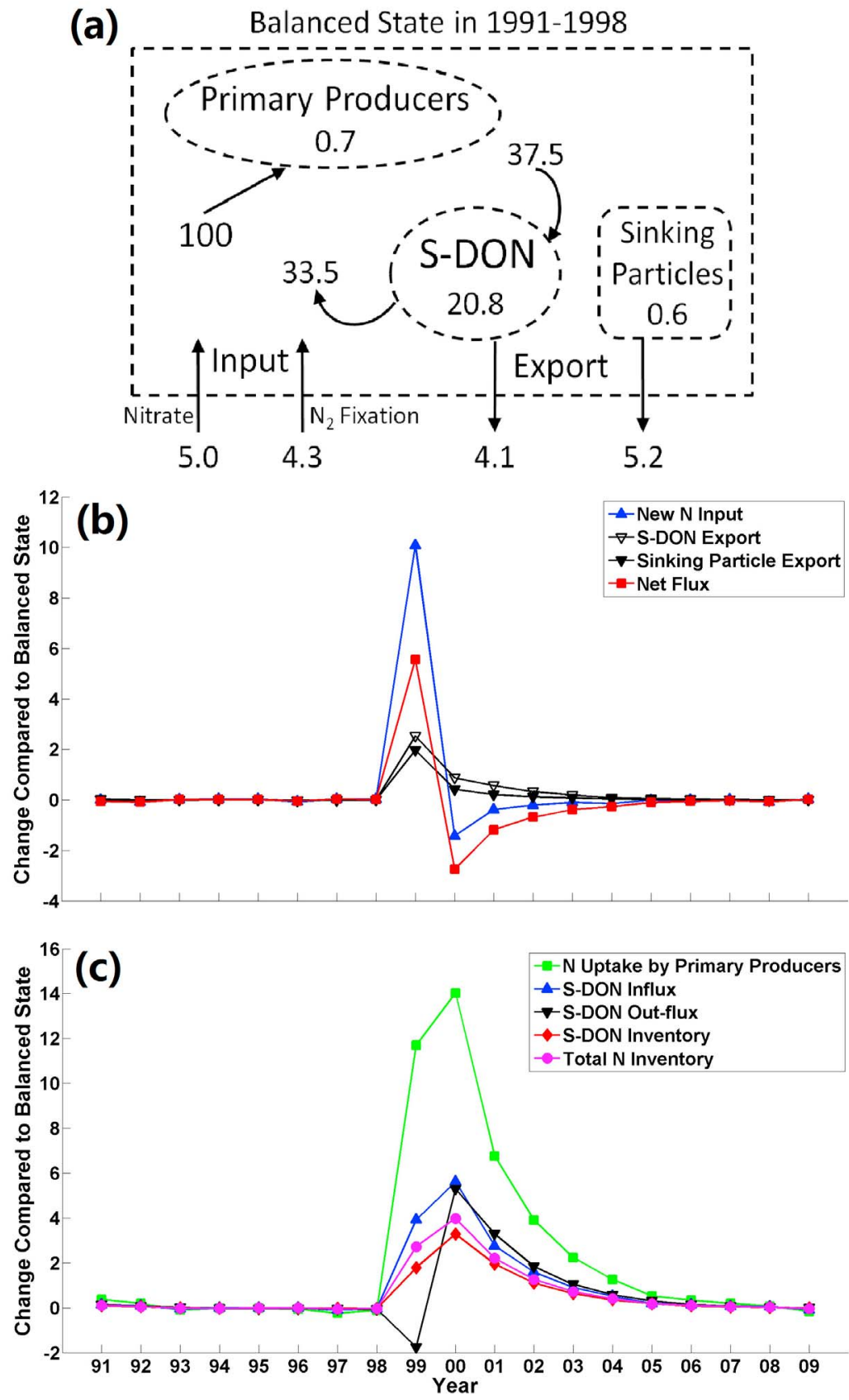

Figure 7. Analysis of annual average $\mathrm{N}$ fluxes in the pulse experiment in $0-150 \mathrm{~m}$, including new $\mathrm{N}$ input (nitrate input plus nitrogen fixation), export of semilabile DON (S-DON) and $\mathrm{N}$ in sinking particles, influx and out-flux of S-DON, as well as S-DON inventory and N biomass of primary producers. All the fluxes are

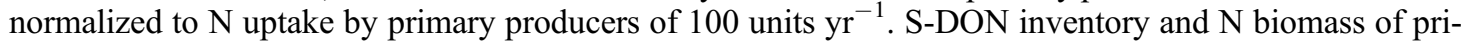
mary producers are normalized to one year of $\mathrm{N}$ uptake by primary producers in 100 units. (a) $\mathrm{N}$ fluxes in the balanced state in 1991-1998. (b) Relative to the balanced state, the new N input (blue up-triangles), $\mathrm{N}$ export in S-DON (black empty down-triangles) and in sinking particles (black filled down-triangles); and the net $\mathrm{N}$ flux to the model domain (red squares). (c) Relative to the balanced state, $\mathrm{N}$ uptake by primary producers (green squares), S-DON influx (blue up-triangles) and out-flux (black down-triangles), S-DON concentration (red diamonds) and total $\mathrm{N}$ inventory in the model (magenta circles).

1999. Part of this nitrate input was converted to and accumulated as semilabile DON, whose recycling supported enhanced primary productivity. In the next several years, as the semilabile DON perturbation was gradually removed via export, the elevated primary productivity also gradually decreased and returned to the previous level.

[37] There is some limited observational evidence to support these model results. Of course the most direct evidence 


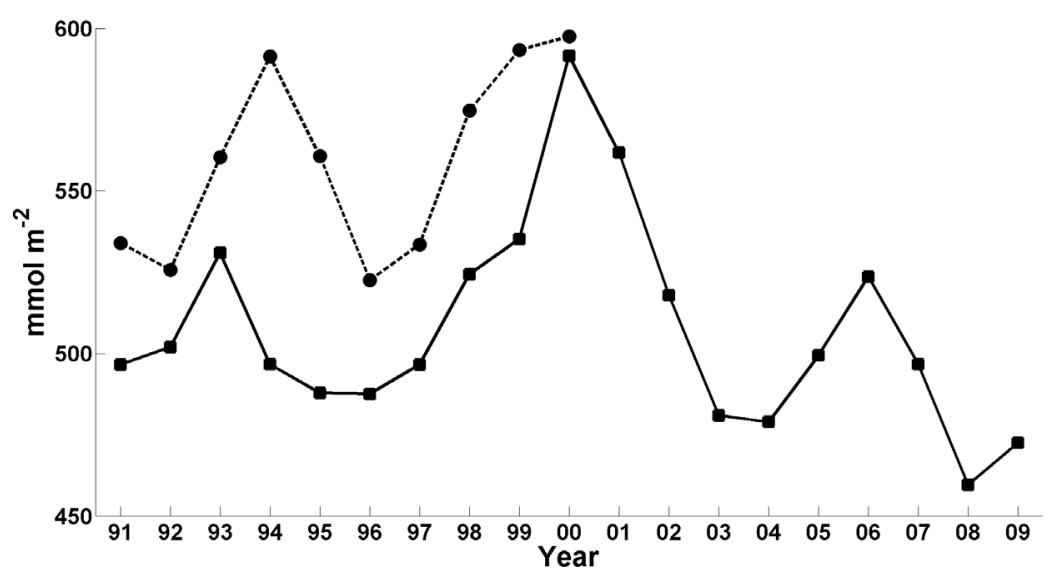

Figure 8. Comparison of annual mean modeled (squares with solid line) and observed (circles with dashed line) semilabile DON at Station ALOHA over 0-150 m. The semilabile DON was derived from the difference of DON measurements between those in $0-150 \mathrm{~m}$ and at $1,000 \mathrm{~m}$ by assuming the latter represented refractory DOM.

would be the interannual variability of in situ measured DON concentration. The HOT data set has DON measurements for 1991-2000, which were used to calculate the semilabile DON concentration by subtracting the concentration at $1,000 \mathrm{~m}$ from the surface concentration. The annual average inventory of both modeled and measured semilabile DON over the upper ocean $(0-150 \mathrm{~m})$ increased in 1997-2000, but the model cannot explain the high semilabile DON measurements in 1994-1995 (Figure 8). Unfortunately there are no observations beyond 2000 to test the model predicted semilabile DON decline after 2000. As mentioned above, we multiplied the average semilabile DON:DOC ratio in 1991-2000 and time series of semilabile DOC concentration after 2000 to reconstruct the bottom boundary conditions for semilabile DON after 2000. However, because of the high variability of the semilabile DON: DOC ratio in 1991-2000, we cannot use the same method to reconstruct $0-150 \mathrm{~m}$ semilabile DON inventory after 2000 for the purpose of evaluating temporal trends.

[38] There was a model misfit where the modeled P-PP started to decrease after 2000 while the measured ${ }^{14} \mathrm{C}$-PP remained elevated through 2002 (Figure 2b). This could be caused by inherent limitations for a vertical 1-D time series observatory and modeling in that they do not resolve changes in properties due to horizontal advection. A Eulerian time series samples different water parcels as they are advected past the fixed location. Strictly speaking, unless the studied properties are horizontally homogeneous over some larger scale, conclusions from a vertical 1-D study are limited. Bidigare et al. [2009] noted a shift to elevated primary production in the field observations at Station ALOHA for the period 1999-2004; their study only went to 2004 and hence did not resolve the subsequent decline in these rates. With a basin-scale three-dimensional model, they found a coincident increase in vertical nitrate flux and zooplankton biomass. Their model study indirectly supports our results, as it suggested that the shift in primary production in 1999 was not a local event but occurred over the whole North Pacific. These authors hypothesized this shift was caused by a different physical mechanism, the post-1998 destratification of the upper ocean in combination with wind mixing events leading to a higher nitrate flux into the euphotic zone. Corno et al. [2007] also proposed a similar hypothesis to explain the increasing primary production at Station ALOHA. However, these studies did not demonstrate that the seasonal destratification was sufficient to deepen the winter mixed-layer into the nitricline. Our experiment with all forcings using seasonal climatologies except for timevarying mixed-layer depth and eddy diffusivity, i.e., forcing the model with destratification, only showed a small increase of P-PP in 1999 (Figure S2 in Text S1 and Table 3), with vertical velocity still the principal driver of this change.

[39] The model had a simplified scheme for DOM by decoupling DOC, DON and DOP dynamics. In reality, a DOM molecule can be DOC only (e.g., hydrocarbons), DOC-N (e.g., amino acids), DOC-P (e.g., sugar phosphates) or DOC-N-P (e.g., nucleotides). This scheme can potentially impact the performance of the model $\mathrm{P}$ cycle. But as discussed above, both the observations and the model revealed that the system was still N-limited. Thus both the observed and the modeled interannual variability of primary production should be determined mainly by the $\mathrm{N}$ cycle, and not greatly impacted by the model P cycle.

\section{Conclusions}

[40] The HOT observations show interannually varying primary production in the North Pacific Subtropical Gyre. Our results suggest that deciphering long-term trends from the more frequent short-term perturbations can be difficult, even with this robust two-decade data set. The North Pacific Subtropical Gyre ecosystem may have experienced stable conditions as suggested by the bounded oscillation of primary production in the 1990s. A series of upwelling-driven nutrient injection events in 1999 may have been strong enough to perturb this stability and significantly increase the primary production. The ecosystem then appears to have returned to the previous state with a relaxation time-scale of several years. In our model simulations, the extra nitrate input in 1999 was mostly converted to and accumulated as semilabile DON. The stored semilabile DON was not quickly exported because of the vertical stratification. In 
addition, compared to other $\mathrm{N}$ pools, the lower lability of semilabile DON in this oligotrophic environment results in relatively low recycling by heterotrophic bacteria, slowing the transfer of the accumulated $\mathrm{N}$ away from rapid export via sinking particles. Instead, the stored semilabile DON was gradually remineralized and recycled over a prolonged period of several years. Our study suggests the ecological impacts of physical nutrient inputs may occur over extended time periods and highlights the importance of DOM-heterotrophic bacterial dynamics in controlling how and for how long oligotrophic subtropical ecosystems can take advantage of extra nutrients brought by mesoscale eddies or other sources of external nutrients.

[41] Acknowledgments. We thank all of the scientists and crew who have contributed to the Hawaii Ocean Time (HOT) series. This work was supported in part by the Center for Microbial Oceanography, Research and Education (C-MORE) (NSF EF-0424599), Hawaii Ocean Time series program (NSF OCE09-26766), the Gordon and Betty Moore Foundation, and the Marine Biological Laboratory. The computational resources were provided by the College of William and Mary SciClone cluster. We thank three anonymous reviewers for their constructive comments, which greatly helped us to improve the quality of this paper.

\section{References}

Azam, F., T. Fenchel, J. G. Field, J. S. Gray, L. A. Meyer-Reil, and F. Thingstad (1983), The ecological role of water-column microbes in the sea, Mar. Ecol. Prog. Ser., 10(3), 257-263, doi:10.3354/meps010257.

Bidigare, R. R., F. Chai, M. R. Landry, R. Lukas, C. C. S. Hannides, S. J. Christensen, D. M. Karl, L. Shi, and Y. Chao (2009), Subtropical ocean ecosystem structure changes forced by North Pacific climate variations, J. Plankton Res., 31(10), 1131-1139, doi:10.1093/plankt/fbp064.

Calil, P. H. R., and K. J. Richards (2010), Transient upwelling hot spots in the oligotrophic North Pacific, J. Geophys. Res., 115, C02003, doi:10.1029/2009JC005360.

Calil, P. H. R., S. C. Doney, K. Yumimoto, K. Eguchi, and T. Takemura (2011), Episodic upwelling and dust deposition as bloom triggers in low nutrient low chlorophyll (LNLC) regions, J. Geophys. Res., 116, C06030, doi:10.1029/2010JC006704.

Carlson, C. A. (2002), Production and removal processes, in Biogeochemistry of Marine Dissolved Organic Matter, edited by D. A. Hansell and C. A. Carlson, pp. 91-151, Elsevier Sci., New York, doi:10.1016/B978012323841-2/50006-3

Carlson, C. A., H. W. Ducklow, and A. F. Michaels (1994), Annual flux of dissolved organic carbon from the euphotic zone in the northwestern Sargasso Sea, Nature, 371, 405-408, doi:10.1038/371405a 0

Casciotti, K. L., T. W. Trull, D. M. Glover, and D. Davies (2008), Constraints on nitrogen cycling at the subtropical North Pacific Station ALOHA from isotopic measurements of nitrate and particulate nitrogen, Deep Sea Res., Part II, 55(14-15), 1661-1672, doi:10.1016/j. dsr2.2008.04.017.

Church, M. J., H. W. Ducklow, and D. M. Karl (2002), Multiyear increases in dissolved organic matter inventories at station ALOHA in the North Pacific Subtropical Gyre, Limnol. Oceanogr., 47(1), 1-10, doi:10.4319/ lo.2002.47.1.0001

Church, M. J., C. Mahaffey, R. M. Letelier, R. Lukas, J. P. Zehr, and D. M. Karl (2009), Physical forcing of nitrogen fixation and diazotroph community structure in the North Pacific subtropical gyre, Global Biogeochem. Cycles, 23, GB2020, doi:10.1029/2008GB003418.

Corno, G., D. M. Karl, M. J. Church, R. M. Letelier, R. Lukas, R. R. Bidigare, and M. R. Abbott (2007), Impact of climate forcing on ecosystem processes in the North Pacific Subtropical Gyre, J. Geophys. Res., 112, C04021, doi:10.1029/2006JC003730.

Deutsch, C., N. Gruber, R. M. Key, and J. L. Sarmiento (2001), Denitrification and $\mathrm{N}_{2}$ fixation in the Pacific Ocean, Global Biogeochem. Cycles, 15(2), 483-506, doi:10.1029/2000GB001291.

Dore, J. E., and D. M. Karl (1996), Nitrite distributions and dynamics at Station ALOHA, Deep Sea Res., Part II, 43(2-3), 385-402, doi:10.1016/0967-0645(95)00105-0.

Dore, J. E., J. R. Brum, L. M. Tupas, and D. M. Karl (2002), Seasonal and interannual variability in sources of nitrogen supporting export in the oligotrophic subtropical North Pacific Ocean, Limnol. Oceanogr., 47(6), 1595-1607, doi:10.4319/lo.2002.47.6.1595.

Ducklow, H. W., C. A. Carlson, N. R. Bates, A. H. Knap, and A. F. Michaels (1995), Dissolved organic carbon as a component of the biological pump in the North Atlantic Ocean, Philos. Trans. R. Soc. London, Ser. B, 348, 161-167, doi:10.1098/rstb.1995.0058.

Friedrichs, M. A. M., et al. (2007), Assessment of skill and portability in regional marine biogeochemical models: Role of multiple planktonic groups, J. Geophys. Res., 112, C08001, doi:10.1029/2006JC003852.

Hedges, J. I. (1992), Global biogeochemical cycles: Progress and problems, Mar. Chem., 39, 67-93, doi:10.1016/0304-4203(92)90096-S.

Jackson, G. A., and P. M. Williams (1985), Importance of dissolved organic nitrogen and phosphorus to biological nutrient cycling, Deep Sea Res. Part A, 32, 223-235, doi:10.1016/0198-0149(85)90030-5.

Karl, D. M., and R. M. Letelier (2008), Nitrogen fixation-enhanced carbon sequestration in low nitrate, low chlorophyll seascapes, Mar. Ecol. Prog. Ser., 364, 257-268, doi:10.3354/meps07547.

Karl, D. M., and R. Lukas (1996), The Hawaii Ocean Time-series (HOT) Program: Background, rationale and field implementation, Deep Sea Res., Part II, 43(2-3), 129-156, doi:10.1016/0967-0645(96)00005-7.

Karl, D. M., R. Letelier, L. Tupas, J. Dore, J. Christian, and D. Hebel (1997), The role of nitrogen fixation in biogeochemical cycling in the subtropical North Pacific Ocean, Nature, 388, 533-538, doi:10.1038/ 41474.

Karl, D. M., D. V. Hebel, K. Björkman, and R. M. Letelier (1998), The role of dissolved organic matter release in the productivity of the oligotrophic North Pacific Ocean, Limnol. Oceanogr., 43(6), 1270-1286, doi:10.4319 lo.1998.43.6.1270.

Karl, D. M., K. M. Björkman, J. E. Dore, L. Fujieki, D. V. Hebel, T. Houlihan, R. M. Letelier, and L. M. Tupas (2001a), Ecological nitrogen-tophosphorus stoichiometry at station ALOHA, Deep Sea Res., Part II, 48(8-9), 1529-1566, doi:10.1016/S0967-0645(00)00152-1.

Karl, D. M., J. E. Dore, R. Lukas, A. F. Michaels, N. R. Bates, and A. Knap (2001b), Building the long-term picture: The U.S. JGOFS time-series programs, Oceanography, 14(4), 6-17, doi:10.5670/oceanog.2001.02.

Karl, D. M., R. R. Bidigare, M. J. Church, J. E. Dore, R. M. Letelier, C. Mahaffey, and J. P. Zehr (2008), The nitrogen cycle in the North Pacific Trades biome: An evolving paradigm, in Nitrogen in the Marine Environment, 2nd ed., edited by D. G. Capone et al., pp. 705-769, Elsevier, Amsterdam, doi:10.1016/B978-0-12-372522-6.00016-5.

Lawson, L. M., Y. H. Spitz, E. E. Hofmann, and R. B. Long (1995), A data assimilation technique applied to a predator-prey model, Bull. Math. Biol., 57(4), 593-617, doi:10.1007/BF02460785.

Letelier, R. M., D. M. Karl, M. R. Abbott, P. Flament, M. Freilich, R. Lukas, and T. Strub (2000), Role of late winter mesoscale events in the biogeochemical variability of the upper water column of the North Pacific Subtropical Gyre, J. Geophys. Res., 105(C12), 28,723-28,739, doi:10.1029/ 1999 JC000306.

Luo, Y. W., M. A. M. Friedrichs, S. C. Doney, M. J. Church, and H. W. Ducklow (2010), Oceanic heterotrophic bacterial nutrition by semilabile DOM as revealed by data assimilative modeling, Aquat. Microb. Ecol., 60(3), 273-287, doi:10.3354/ame01427.

McCarren, J., J. W. Becker, D. J. Repeta, Y. M. Shi, C. R. Young, R. R. Malmstrom, S. W. Chisholm, and E. F. DeLong (2010), Microbial community transcriptomes reveal microbes and metabolic pathways associated with dissolved organic matter turnover in the sea, Proc. Natl. Acad. Sci. U. S. A., 107(38), 16,420-16,427, doi:10.1073/pnas.1010732107.

Monod, J. (1949), The growth of bacterial cultures, Annu. Rev. Microbiol., 3(1), 371-394, doi:10.1146/annurev.mi.03.100149.002103.

Redfield, A. C. (1958), The biological control of chemical factors in the environment, Am. Sci., 46, 205-221.

Saba, V. S., et al. (2010), Challenges of modeling depth-integrated marine primary productivity over multiple decades: A case study at BATS and HOT, Global Biogeochem. Cycles, 24, GB3020, doi:10.1029/ 2009GB003655

Sverdrup, H. U., M. W. Johnson, and R. H. Fleming (1942), The Oceans, Their Physics, Chemistry, and General Biology, Prentice-Hall, New York.

Vaillancourt, R. D., J. Marra, M. P. Seki, M. L. Parsons, and R. R. Bidigare (2003), Impact of a cyclonic eddy on phytoplankton community structure and photosynthetic competency in the subtropical North Pacific Ocean, Deep Sea Res., Part I, 50(7), 829-847, doi:10.1016/S09670637(03)00059-1. 